\title{
PENYELESAIAN SENGKETA BISNIS MELALUI LEMBAGA ARBITRASE
}

\author{
Ni Nyoman Adi Astiti \\ Sekolah Tinggi Ilmu Hukum Tambun Bungai Palangka Raya \\ Email: nyoman.stihtb@gmail.com
}

\author{
Jefry Tarantang \\ Insitut Agama Islam Negeri Palangka Raya \\ Email: hukumtarantang@gmail.com
}

\begin{abstract}
Abstrak
Penyelesaian sengketa melalui lembaga arbitrase banyak diminati oleh para pelaku bisnis, sebab penyelesaian sengketa melalui lembaga arbitrase memiliki kelebihan dibanding lembaga pengadilan yang bersifat formal. Kelebihan lain lembaga arbitrase diantaranya yaitu proses cepat dan sederhana, biaya murah, kerahasiaan sengketa terjaga, putusan bersifat merangkul dan menguntungkan para pihak (win-win solution), serta menjaga hubungan bisnis para pihak, sehingga dijadikan pilihan oleh pelaku bisnis. Penelitian ini merupakan penelitian yuridis normatif. Metode pendekatan yang digunakan adalah metode yuridis normatif yaitu penelitian yang menekankanpada data sekunder yakni dengan mempelajari dan mengkaji azas-azas hukum khususnya kaidah-kaidah hukum dalam peraturan perundang-undangan serta ketentuanketentuan yang berkaitan dengan penyelesaian sengketa bisnis melalui lembaga arbitrase dan eksekusi putusan lembaga arbitrase dalam penyelesaian sengketa bisnis.

Hasil dari penelitian ini dapat disimpulkan seperti berikut. (1) Penyelesaian sengketa bisnis melalui lembaga arbitrase dilakukan dengan dua cara yaitu melalui factum de compromittendo, sebelum terjadi sengketa klausula arbitrase telah dicantumkan dalam perjanjian pokok, atau melalui akta kompromis setelah terjadi sengketa klausula arbitrase dibuat dalam bentuk tertulis terpisah dari perjanjian pokok. Sedangkan proses penyelesaian sengketa melalui lembaga arbitrase menurut Pasal 27 sampai dengan 60 Undang-Undang Nomor 30 Tahun 1999 dan memiliki keputusan lembaga arbitrase bersifat final dan mempunyai kekuatan hukum tetap dan mengikat para pihak, para pihak harus terikat dalam putusan arbitrase tersebut, walaupun pada tahap eksekusinya masih memerlukan keterlibatan Pengadilan Negeri. (2) Eksekusi putusan lembaga arbitrase dalam penyelesaian sengketa bisnis sebagaimana diatur dalam Pasal 59 sampai dengan 64 dari UU No. 30 Tahun 1999 dalam waktu paling lama 30 (tiga puluh) hari terhitung sejak tanggal putusan diucapkan, lembar asli atau salinan otentik putusan arbitrase diserahkan dan didaftarkan oleh arbiter kepada Panitera Pengadilan Negeri untuk dilakukan pengujian syarat formil dan syarat materil oleh Ketua Pengadilan Negeri yang menjadikan putusan lembaga arbitrase memiliki kekuatan hukum mengikat yang bersifat final and binding.
\end{abstract}

Kata Kunci: sengketa bisnis, lembaga arbitrase

\section{PENDAHULUAN}

Mengamati kegiatan bisnis yang jumlah transaksinya ratusan setiap hari, tidak mungkin dihindari terjadinya sengketa (dispute/difference) antarpihak yang terlibat. Setiap segala jenis sengketa yang terjadi selalu menuntut pemecahan dan penyelesaian yang cepat. Makin banyak dan luas kegiatan perdagangan, frekuensi terjadinya sengketa makin tinggi. Hal ini berarti 
semakin banyak sengketa harus diselesaikan. ${ }^{1}$ Sengketa bisnis diakibatkan oleh praktek bisnis yang tidak sesuai dengan isi kontrak dalam perjanjian bisnis, seperti beda pendapat, beda pemahaman, dan beda penafsiran oleh para pihak dan tidak terpenuhinya hak dan kewajiban yang telah disepakati dalam kontrak bisnis dapat menimbulkan sengketa bisnis. ${ }^{2}$

Sebagai penanggulangan dan cara penyelesaian sengketa bisnis, maka dalam penyusunan atau perancangan kontrak atau perjanjian bisnis dapat dibuat klausula tata cara penyelesaian sengketa. Hal ini merupakan konsekuensi logis dari diberlakukannya prinsip kebebasan berkontrak (freedom of contract), maka para pihak dapat menentukan sendiri tata cara penyelesaian sengketa bisnis yaitu meliputi pilihan hukum (choice of law), pilihan forum (choice of jurisdiction), dan pilihan domisili (choice of domicile). ${ }^{3}$ Hal ini ditegaskan pada Pasal $1338 \mathrm{KUH}$ Perdata yaitu berlaku azas pacta sunt servanda. Artinya perjanjian yang dibuat oleh pihak-pihak menetapkan kewajiban hukum untuk dilaksanakan oleh pihak-pihak. Lebih lanjut menurut Abdulkadir Muhammad, menjelaskan bahwa "perjanjian mengikat para pihak yang membuatnya. Perjanjian berlaklu sebagai undang-undang bagi pihak-pihak yang membuatnya. Perjanjian harus dilaksanakan dengan itikad baik (te goeder trouw, Pasal 1338 KUHPerdata)."4

Penyelesaian sengketa di bidang bisnis yang juga meliputi sengketa bisnis dapat diselesaikan melalui dua cara atau pilihan hukum (choice of law) yaitu melalui lembaga litigasi oleh lembaga pengadilan umum dan melalui lembaga nonlitigasi atau melalui alternatif penyelesaian sengketa (Alternative Dispute Resolution/ADR) dengan cara negosiasi, mediasi, konsiliasi, dan arbitrase. Secara umum penyelesaian sengketa dengan cara arbitrase (arbitrare dalam bahasa latin) di Indonesia dalam skala nasional diselenggarakan melalui lembaga arbitrase, dikenal ada dua macam, yaitu Arbitrase Institusional (bersifat permanen atau melembaga sebagai organisasi) dan Arbitrase Ad Hoc (bersifat sementara atau temporer). Lembaga arbitrase institusional di Indonesia yang keberadaannya telah membantu penyelesaian sengketa secara non litigasi yang diselenggarakan oleh Badan Arbitrase Nasional Indonesia (selanjutnya disingkat BANI) yang didirikan oleh Kamar Dagang dan Industri pada tanggal 3 Desember $1977 . .^{5}$

Tata cara penyelesaian sengketa yang dibuat dalam suatu perjanjian yang memuat klausul arbitrase, yaitu dibuat sebelum terjadi sengketa, dapat bersamaan dengan saat pembuatan perjanjian pokok atau sesudahnya (pactum de compromitendo) dan dibuat setelah terjadinya sengketa yang berkenaan dengan pelaksanaan suatu perjanjian (acta compromise), ${ }^{6}$ sebagaimana terdapat pada Pasal 2 Undang-Undang Nomor 30 Tahun 1999 Tentang Arbitrase dan Alternatif Penyelesaian Sengketa (selanjutnya disingkat UU No. 30 Tahun 1999) menyebutkan bahwa:

Undang-undang ini mengatur penyelesaian sengketa atau beda pendapat antar pihak dalam suatu hubungan hukum tertentu yang telah mengadakan perjanjian arbitrase yang secara tegas menyatakan bahwa semua sengketa atau beda pendapat yang timbul atau yang mungkin timbul dari hubungan hukum tersebut diselesaikan dengan cara arbitrase atau melalui alternatif penyelesaian sengketa. ${ }^{7}$

\footnotetext{
${ }^{1}$ Suyud Margono, ADR (Alternative Dispute Resolution) \& Arbitrase Proses Pelembagaan dan Aspek Hukum, Bogor, Ghalia Indonesia, 2004, Hal. 12.

${ }^{2}$ Endang Purwaningsih, Hukum Bisnis, Bogor, Ghalia Indonesia, 2010, Hal. 268-269.

${ }_{3}^{3}$ Munir Fuady, Hukum Kontrak (Dari Sudut Pandang Hukum Bisnis), Bandung: PT Citra Aditya Bakti, 2007, Hal. 137.

${ }^{4}$ Abdulkadir Muhammad, Hukum Perdata Indonesia, Bandung, PT. Citra Aditya Bakti, 2009, Hal. 21.

5R. Subekti, Aneka Perjanjian, Bandung, PT. Citra Aditya Bakti, 1995, Hal. 182.

${ }^{6}$ Joni Emirzon, Alternatif Penyelesaian Sengketa di Luar Pengadilan (Negosiasi, Mediasi, Konsiliasi \& Arbitrase), Jakarta, Gramedia Pustaka Utama, 2000, Hal.100-101.

${ }^{7}$ Pasal 2 Undang-Undang Nomor 30 Tahun 1999 Tentang Arbitrase dan Alternatif Penyelesaian Sengketa.
} 
Sebelum menentukan penyelesaian sengketa melalui arbitrase para pihak atau diwakili kuasa hukumnya terlebih dahulu melakukan musyawarah untuk mufakat untuk menghasilkan kesepakatan yang menguntungkan para pihak, namun apabila tidak menghasilkan kesepakatan, maka para pihak akan menyelesaikan sengketa dengan cara arbitrase. Penyelesaian sengketa melalui lembaga arbitrase memiliki putusan yang besifat final dan mengikat (final and binding) bagi para pihak yang bersengketa, dengan adanya lembaga arbitrase, maka putusan yang telah ditetapkan oleh lembaga arbitrase tidak boleh untuk diajukan lagi ke pengadilan berdasarkan azas pacta sunt servanda pada Pasal 1338 KUHPerdata. ${ }^{8}$

Alternatif penyelesaian sengketa melalui lembaga abitrase di Indonesia dikenal dua macam, yaitu Arbitrase Institusional (bersifat permanen atau melembaga sebagai organisasi) dan Arbitrase Ad Hoc (bersifat sementara atau temporer). Lembaga arbitrase institusional di Indonesia yang keberadaannya telah membantu penyelesaian sengketa secara non litigasi yang diselenggarakan oleh Badan Arbitrase Nasional Indonesia (selanjutnya disingkat BANI) yang didirikan oleh Kamar Dagang dan Industri pada tanggal 3 Desember 1977. ${ }^{9}$

Penyelesaian sengketa melalui lembaga arbitrase banyak diminati oleh para pelaku bisnis, sebab penyelesaian sengketa melalui lembaga arbitrase memiliki kelebihan dibanding lembaga pengadilan yang bersifat formal. Kelebihan lain lembaga arbitrase di antaranya yaitu proses cepat dan sederhana, biaya murah, kerahasiaan sengketa terjaga, putusan bersifat merangkul dan menguntungkan para pihak (win-win solution), serta menjaga hubungan bisnis para pihak, sehingga dijadikan pilihan oleh pelaku bisnis. ${ }^{10}$

\section{Aspek Hukum Penyelesaian Sengketa Bisnis Secara Umum}

Proses penyelesaian sengketa yang sudah dikenal sejak lama adalah melalui proses litigasi di pengadilan. Proses litigasi cenderung menghasilkan masalah baru karena sifatnya yang win-lose, tidak responsif, time consuming proses berperkaranya, dan terbuka untuk umum. Seiring dengan perkembangan zaman, proses penyelesaian sengketa di luar pengadilan pun ikut berkembang. Penyelesaian sengketa di luar pengadilan bersifat tertutup untuk umum (close door session) dan kerahasiaan para pihak terjamin (confidentiality), proses beracara lebih cepat dan efisien. Proses penyelesaian sengketa di luar pengadilan ini menghindari kelambatan yang diakibatkan prosedural dan administratif sebagaimana beracara di pengadilan umum dan win-win solution. ${ }^{11}$ Penyelesaian sengketa di luar pengadilan ini disebut dengan Alternatif Penyelesaian Sengketa (APS) atau Alternative Dispute Resolution (ADR.) ${ }^{12}$

Sejarah munculnya APS dimulai pada tahun 1976 ketika Ketua Mahkamah Agung Amerika Serikat Warren Burger mempelopori ide ini pada suatu konferensi di Saint Paul, Minnesota Amerika Serikat.Hal ini dilatarbelakangi oleh berbagai faktor gerakan reformasi pada awal tahun 1970, di mana saat itu banyak pengamat dalam bidang hukum dan masyarakat akademisi mulai merasakan adanya keprihatinan yang serius mengenai efek negatif yang semakin meningkat dari litigasi di pengadilan. Akhirnya American Bar Assosiation (ABA) merealisasikan rencana itu dan selanjutnya menambahkan Komite APS pada organisasi mereka diikuti dengan masuknya kurikulum APS pada sekolah hukum di Amerika Serikat dan juga pada sekolah ekonomi. ${ }^{13}$

\footnotetext{
${ }^{8}$ Richard Burton Simatupang, Aspek Hukum dalam Bisnis,Jakarta, PT. Rineka Cipta, 2003, Hal. 51.

${ }^{9}$ R. Subekti, Aneka Perjanjian, Bandung, PT. Citra Aditya Bakti, 1995, Hal. 182.

${ }^{10}$ Frans Hendra Winarta, Hukum Penyelesaian Sengketa Arbitrase Nasional Indonesia dan Arbitrase Internasional, Jakarta, Sinar Grafika, 2013, Hal. 9.

${ }^{11}$ Ibid.

${ }^{12}$ M. Yahya Harahap, Hukum Acara Perdata Gugatan Persidangan, Penyitaan, Pembuktian, dan Putusan Pengadilan, Jakarta, Sinar Grafika, 2008, Hal. 236.

${ }^{13}$ Frans Hendra Winarta, Hukum Penyelesaian Sengketa Arbitrase Nasional Indonesia dan Arbitrase Internasional, Jakarta, Sinar Grafika, 2013, Hal. 10.
} 
APS pertama kali berkembang di negara Amerika Serikat, di mana pada saat itu APS berkembang karena dilatarbelakangi hal-hal sebagai berikut.

- Mengurangi kemacetan di pengadilan. Banyaknya kasus yang diajukan ke pengadilan menyebabkan proses pengadilan sering-kali berkepanjangan, sehingga memakan biaya yang tinggi dan sering memberikan hasil yang kurang memuaskan.

- Meningkatkan ketertiban masyarakat dalam proses penyelesaian sengketa.

- Memperlancar serta memperluas akses ke pengadilan.

- Memberikan kesempatan bagi tercapainya penyelesaian sengketa yang menghasilkan keputusan yang dapat diterima oleh semua pihak dan memuaskan. ${ }^{14}$

Sebenarnya jiwa dari alternatif penyelesaian sengketa itu sudah ada dari nenek moyang bangsa Indonesia. Hal itu sebagaimana terlihat ternyata dalam budaya musyawarah untuk mencapai mufakat yang aasih sangat terlihat di masyarakat pedesaan di Indonesia, di mana ketika ada sengketa di antara mereka, cenderung masyarakat tidak membawa permasalahan tersebut ke pengadilan, namun diselesaikan cara kekeluargaan. Apabila sengketa tersebut tidak dapat diselesaikanantara para pihak yang bersengketa, maka mereka akan membawa sengketa mereka tersebut ke hadapan kepala desa. Dengan semangat musyawarah untuk mencapai mufakat yang sudah mengakar dalam bangsa Indonesia, APS mempunyai potensi yang sangat besar untuk dikembangkan dan digunakan oleh para praktisi hukum di Indonesia, pentingnya peran APS dalam menyelesaikan sengketa semakin besar dengan diundangkannya UU No. 30 Tahun 1999.15

Cara penyelesaian sengeketa yang diatur dalam UU No. 30 Tahun 1999, yaitu Alternative Dispute Resolution (ADR), melalui beberapa cara penyelesaian sengketa yaitu konsultasi; negosiasi; mediasi; konsiliasi; dan penilaian ahli.

APS yang diatur dalam UU No. 30 Tahun 1999 disebutkan dalam Pasal 1 angka 10 menyebutkan APS sebagai lembaga penyelesaian sengketa atau beda pendapat melalui prosedur yang disepakati para pihak, yakni penyelesaian di luar pengadilan dengan cara konsultasi, negosiasi, mediasi, konsiliasi, atau penilaian ahli.Dalam perancangan UU No. 30 Tahun 1999, Sudargo Gautama menyatakan bahwa terdapat 2 (dua) aliran dalam APS, yaitu aliran yang menyatakan bahwa arbitrase terpisah dari APS dan aliran yang menyatakan bahwa arbitrase termasuk dalam APS. Namun demikian, pada saat disahkan dan diundangkannya UU No. 30 Tahun 1999, arbitrase dipisahkan dari APS. Dapat disimpulkan bahwa APS adalah pranata penyelesaian sengketa di luar pengadilan berdasarkan kesepakatan para pihak dengan mengesampingkan penyelesaian sengketa melalui proses litigasi di pengadilan. ${ }^{16}$

\section{Dasar Hukum Lembaga Arbitrase}

Arbitrase berasal dari arbitrare (bahasa Latin) yang berarti kekuasaan untuk menyelesaikan sesuatu menurut kebijaksanaan. Dihubungkannya arbitrase dengan kebijaksanaan itu, dapat menimbulkan salah kesan seolah-olah seorang arbiter atau suatu majelis arbitrase dalam menyelesaikan suatu sengketa tidak mengindahkan norma-norma hukum lagi dan menyandarkan pemutusan sengketa tersebut hanya pada kebijaksanaan saja. Kesan tersebut keliru, karena arbiter atau majelis tersebut juga menerapkan hukum seperti apa yang dilakukan oleh hakim atau pengadilan. Berikut adalah beberapa definisi mengenai arbitrase. Berdasarkan UU No. 30 Tahun 1999, arbitrase adalah cara penyelesaian suatu sengketa perdata di luar

\footnotetext{
${ }^{14}$ Frans Hendra Winarta, Hukum Penyelesaian Sengketa Arbitrase Nasional Indonesia dan Arbitrase Internasional, Jakarta, Sinar Grafika, 2013, Hal. 10.

${ }^{15}$ Ibid., Hal. 11.

${ }^{16}$ Ibid., Hal. 14-15.
} 
peradilan umum yang didasarkan pada perjanjian arbitrase yang dibuat secara tertulis oleh para pihak yang bersengketa. ${ }^{17}$

Arbitrase sebagaimana dimaksud dalam UU No. 30 Tahun 1999 adalah cara penyelesaian suatu sengketa perdata di luar peradilan umum yang didasarkan pada perjanjian arbitrase yang dibuat secara tertulis oieh para pihak yang bersengketa. Apabila para pihak telah terikat perjanjian arbitrase, maka pengadilan negeri tidak berwenang untuk mengadili sengketa para pihak tersebut. Dengan demikian, pengadilan wajib mengakui dan menghormati wewenang dan fungsi arbiter.

Namun perlu diingat, bahwa kebolehan mengikat diri dalam perjanjian arbitrase, harus didasarkan atas kesepakatan bersama (mutual consent). Faktor kesukarelaan dan kesadaran bersama merupakan landasan keabsahan ikatan perjanjian arbitrase. Berdasarkan hal tersebut, keabsahan dan mengikatnya setiap perjanjian arbitrase, harus memenuhi ketentuan Pasal 1320 KUHPerdata. Mengenai pilihan hukum, para pihak bebas menentukan pilihan hukum rang akan berlaku terhadap penyelesaian sengketa yang mungkin atau telah timbul antara para pihak. ${ }^{18}$

Pengaturan arbitrase sebagaimana Pasal 7 UU No. 30 Tahun 1999 mengatur bahwa para pihak dapat menyetujui perjanjian suatu sengketa yang terjadi atau yang akan terjadi di antara mereka untuk diselesaikan melalui arbitrase dengan suatu perjanjian tertulis yang disepakati para pihak. Adanya perjanjian tertulis meniadakan hak para pihak untuk mengajukan penyelesaian sengketa atau beda pendapat yang termuat dalam perjanjiannya ke pengadilan negeri. ${ }^{19}$

Arbitrase merupakan suatu cara penyelesaian sengketa perdata di luar peradilan umum yang hanya didasarkan pada perjanjian arbitrase yang dibuat tertulis oleh para pihak yang bersengketa. ${ }^{20}$ Menurut M. Husein dan A. Supriyani, Arbitrase berasal dari kata arbitrare (bahasa latin) yang berarti kekuasaan untuk menyelesaikan sesuatu perkara menurut kebijaksanaan. Sedangkan menurut Frank Elkoury dan Edna Elkoury, arbitration adalah suatu proses yang mudah yang dipilih oleh para pihak secara sukarela karena ingin agar perkaranya diputus oleh juru pisah yang netral sesuai dengan pilihan di mana keputusan mereka berdasarkan dalildalil dalam perkara tersebut. Para pihak setuju sejak semula untuk menerima putusan tersebut secara final dan mengikat. ${ }^{21}$

Menurut Gary Goodpaster, arbitration is the private adjudication of dispute parties, anticipating posible dispute or experience an actual dispute, agree to submit their dispute to a decision maker they in some fashion select. Menurut Black's Law Dictionary dijelaskan bahwa arbitration is the reference of a dispute to an impartial (third) person chosen by the parties to the dispute who agree in advance to abide by the arbitrator's award issued after hearing at which both parties have an opportunity to be heard. Lebih lanjut dijelaskan bahwa: An arrangement for taking and abiding by the judgment of selected persons in some disputed matter, instead of carring it to establish tribunal justice, and is intended to avoid the formalities, the delay, the expense and taxation of ordinary litigation. ${ }^{22}$

Menurut R. Subekti, arbitrase adalah pemutusan suatu sengketa oleh seorang atau beberapa orang yang ditunjuk oleh para pihak yang bersengketa sendiri, di luar hakim atau

\footnotetext{
${ }^{17}$ Ibid., Hal. 36.

${ }^{18}$ Ibid., Hal. 37.

${ }^{19}$ Ibid., Hal. 37.

${ }^{20}$ M. Marwan, dan Jimmy P., Kamus Hukum (Dicionary of Law Complete Edition), Surabaya, Reality Publisher, 2009, Hal. 54.

${ }^{21}$ Joni Emirzon, Alternatif Penyelesaian Sengketa di Luar Pengadilan (Negosiasi, Mediasi, Konsiliasi \& Arbitrase), Jakarta, Gramedia Pustaka Utama, 2000, Hal.96.

${ }^{22}$ Ibid.
} 
pengadilan. Orang yang ditunjuk untuk memutuskan sengketa dinamakan arbiter atau wasit. ${ }^{23}$ Adapun menurut Sophar Maru Hutagalung, arbitrase adalah cara penyelesaian suatu sengketa perdata di luar peradilan umum yang didasarkan pada perjanjian arbitrase yang dibuat secara tertulis oleh pihak yang bersengketa. Perjanjian arbitrase adalah suatu kesepakatan berupa klausul arbitrase yang tercantum dalam suatu perjanjian tertulis yang dibuat para pihak sebelum timbul sengketa, atau suatu perjanjian arbitrase tersendiri yang dibuat para pihak setelah timbul sengketa. ${ }^{24}$ Dengan demikian pada dasarnya arbitrase merupakan suatu proses penyelesaian sengketa para pihak yang dilakukan secara musyawarah dengan menunjuk pihak ketiga sebagai wasit, yang dituangkan dalam suatu kontrak. ${ }^{25}$

Secara filosofis, UU No. 30 Tahun 1999 adalah untuk mengakhiri hubungan hukum para pihak yang mengadakan perjanjian arbitrase dalam keadaan seperti semula, sehingga mereka dapat mengadakan perjanjian lebih lanjut. Landasan sosiologis ditetapkan UU No. 30 Tahun 1999 adalah karena banyaknya timbul sengketa yang terjadi di antara para pihak yang mengadakan perjanjian arbitrase. Landasan Yuridis ditetapkannya UU No. 30 Tahun 1999 adalah karena peraturan perundang-undangan yang kini berlaku untuk penyelesaian sengketa melalui arbitrase sudah tidak sesuai lagi dengan perkembangan dunia usaha dan hukum pada umumnya. ${ }^{26}$

Klausul arbitrase adalah mengenai hal-hal yang boleh dicantumkan dalam perjanjian arbitrase. Penggunaan istilah klausul arbitrase mengandung konotasi bahwa perjanjian pokok yang bersangkutan diikuti atau dilengkapi dengan persetujuan mengenai pelaksanaan arbitrase. Klausul arbitrase dalam sebuah perjanjian pada umumnya secara spesifik memberi para pihak kekuasaan yang besar berkaitan dengan beberapa aspek. Klausul arbitrase mungkin menunjuk sebuah badan arbitrase tertentu, lokasi arbitrase berlangsung, hukum dan aturan-aturan yang akan digunakan, kualifikasi para arbiter, dan bahasa yang akan dipakai dalam proses arbitrase. ${ }^{27}$

Pasal 5 UU No. 30 Tahun 1999 menyatakan bahwa sengketa yang dapat diselesaikan melalui arbitrase hanya sengketa di bidang perdagangan dan mengenai hak yang menurut hukum dan peraturan perundang-undangan dikuasai sepenuhnya oleh pihak yang bersengketa. Sengketa yang tidak dapat diselesaikan oleh lembaga arbitrase adalah sengketa yang menurut aturan perundang-undangan tidak dapat diadakan perdamaian. ${ }^{28}$

\section{Kedudukan dan Fungsi Lembaga Arbitrase dalam Penyelesaian Sengketa Bisnis}

Lembaga arbitrase disebut lembaga perwasitan. Para anggota dari lembaga arbitrase terdiri dari berbagai keahlian, antara lain, ahli dalam perdagangan, industri, perbankan, dan hukum. Sebenarnya, masalah penyelesaian sengketa bisnis atau perdagangan melalui lembaga arbitrase bukanlah sesuatu hal yang baru dalam praktek hukum di indonesia. Disebut demikian karena pada zaman hindia Belanda pun sudah dikenal. Hanya saja, pada waktu itu berlaku untuk golongan tertentu saja sehingga pengaturan lembaga ini pun diatur tersendiri yakni dalam hukum acara perdata yang berlaku bagi golongan Eropa yang termuat dalam reglement op de rechtelijke rechtsvordering (RV). Dalam Pasal 615 Rv ditegaskan adalah diperkenankan kepada siapa saja yang terlibat dalam suatu sengketa mengenai hak-hak yang berada dalam

\footnotetext{
${ }^{23}$ R. Subekti, Aneka Perjanjian, Bandung, PT. Citra Aditya Bakti, 1995, Ha. 181.

${ }^{24}$ Sophar Maru Hutagalung, Praktik Peradilan Perdata dan Alternatif Penyelesaian Sengketa, Jakarta, Sinar Grafika, 2012, Hal. 314315.

${ }^{25}$ Joni Emirzon, Alternatif Penyelesaian Sengketa di Luar Pengadilan (Negosiasi, Mediasi, Konsiliasi \& Arbitrase), Jakarta, Gramedia Pustaka Utama, 2000, Hal.97.

${ }^{26}$ Ibid.,Hal. 139.

${ }^{27}$ Frans Hendra Winarta, Hukum Penyelesaian Sengketa Arbitrase Nasional Indonesia dan Arbitrase Internasional, Jakarta, Sinar Grafika, 2013, Hal. 42

${ }^{28}$ Ibid.,Hal. 42.
} 
kekuasaannya untuk menyelesaikan sengketa tersebut kepada seseorang atau beberapa orang wasit (arbiter).

Apabila diperhatikan secara sepintas isi Pasal tersebut, seolah-olah setiap sengketa dapat diselesaikan oleh lembaga ini, tetapi tidaklah demikian halnya karena yang dapat diselesaikan oleh lembaga arbitrase adalah hanya yang menyangkut kekuasaan para pihak yang bersengketa, yakni tentang hak dan kewajiban yang timbul dalam perjanjian. Untuk itu ada baiknya perlu diperhatikan azas yang tercantum dalam Pasal 1338 ayat (1) KUHPerdata yang mengemukakan bahwa : "Semua perjanjian yang dibuat secara sah berlaku sebagai undang-undang bagi mereka yang membuatnya."

Jadi apa yang telah disepakati oleh kedua belah pihak yang berjanji, maka bagi mereka hal tersebut dianggap merupakan suatu undang-undang yang harus ditaati. Dalam praktek dunia bisnis yang berlaku sekarang, sudah ada suatu standar kontrak yang baku, karenanya para pihak tinggal mempelajarinya, apakah ia setuju atau tidak terhadap syarat-syarat yang tercantum dalam kontrak tersebut. Biasanya dalam standar kontrak dicantumkan suatu klausul bahwa apabila terjadi suatu perselisihan atau perbedaan penafsiran tentang isi perjanjian, akan diselesaikan oleh lembaga arbitrase (badan perwasitan). Hal ini berarti sejak para pihak menyetujui dan menandatangani kontrak tersebut, sudah menyatakan diri bahwa perselisihan yang mungkin akan terjadi diselesaikan oleh lembaga arbitrase.

Tetapi, dapat pula terjadi bahwa dalam suatu kontrak tidak ada klausul tersebut, tetapi jika dikehendaki oleh para pihak apabila ada perselisihan masih dapat diselesaikan oleh lembaga arbitrase, yakni berdasarkan persetujuan kedua belah pihak, tetapi harus dibuat secara tertulis. Adapun tugas lembaga arbitrase adalah menyelesaikan persengketaan yang diserahkan kepadanya berdasarkan suatu perjanjian yang telah disepakati oleh para pihak yang bersengketa.

Pasal 1 angka 8 UU No 30 Tahun 1999 memberikan defenisi mengenai lembaga arbitrse yaitu: "Badan yang dipilih oleh para pihak yang bersengketa untuk memberikan putusan mengenai sengketa tertentu, lembaga tersebut juga dapat menberikan pendapat yang mengikat mengenai suatu hubungan hukum tertentu dalam hal belum timbul sengketa".

Jika dicermati dalam praktik dunia bisnis yang berkembang dewasa ini, tampak bahwa dalam suatu kontrak apakah ia yang sudah baku ataupun belum sudah ada suatu klausul arbitrase, artinya jika timbul perselisihan akan diselesaikan oleh lembaga ini. Tampaknya, penyelesaian sengketa bisnis di luar pengadilan (Out of Court Settlement) semakin banyak diminta sebab ada beberapa keuntungan yang dapat diperoleh, yakni prosedurnya cukup cepat dan rahasia perusahaan lebih terjamin. Penyelesaian sengketa di luar pengadilan dikenal dengan Alternative Dispute Resolution atau Metode Alternatif Penyelesaian Sengketa (ADR atau MAPS). Azas penyelesaian sengketa di luar pengadilan, yaitu putusan harus dijalankan secara sukarela oleh pihak yang bersengketa. Di Indonesia sendiri, penyelesaian sengketa di luar pengadilan diatur dalam Undang-Undang Nomor 30 Tahun 1999 tentang Arbitrase dan Alternatif Penyelesaian Sengketa, Lembaran Negara Republik Indonesia Nomor 138 tahun 1999 tanggal 12 Agustus 1999.

\section{Penyelesaian Sengketa Bisnis Melalui Lembaga Arbitrase}

Arbitrase merupakan cara penyelesaian sengketa melalui "adjudikatif privat", yang putusannya bersifat final dan mengikat. Dalam ketentuan Pasal 3 UU No. 30 Tahun 1999 disebutkan bahwa Pengadilan Negeri tidak berwenang untuk mengadili sengketa para pihak yang telah terikat dalam perjanjian arbitrase. Adapun objek pemeriksaan Arbitrase adalah memeriksa sengketa keperdataan, tetapi tidak semua sengketa keperdataan dapat diselesaikan 
melalui arbitrase, hanya bidang tertentu yang disebutkan dalam Pasal 5 ayat (1) UU No. 30 Tahun 1999 yaitu: "Sengketa yang dapat diselesaikan melalui arbitrase hanya sengketa di bidang perdagangan dan mengenai hak yang menurut hukum dan peraturan perundangundangan dikuasai sepenuhnya oleh pihak yang bersengketa".

Penyelesaian sengketa dengan menggunakan arbitarase BANI jika sidang pertama pemohon tidak hadir, tanpa adanya alasan yang sah, maka permohonan arbitrase akan dinyatakan gugur. Hal ini sesuai dengan ketentuan HIR mengenai perkara perdata. Namun jika termohon yang tidak datang pada sidang pertama, maka akan dipanggil sekali lagi untuk menghadap di muka sidang pada waktu kemudian yang ditetapkan selambat-lambatnya empat belas hari lagi sejak dikeluarkannya perintah tersebut. Jika termohon tidak datang juga, maka pemeriksaan akan diteruskan tanpa hadirnya si termohon dan tuntutan si pemohon akan dikabulkan, kecuali tuntutan itu oleh BANI dianggap tidak berdasarkan hukum atau keadilan. Jadi ketentuan ini sesuai dengan verstek dalam HIR. Ini berarti BANI termasuk ke dalam arbitrase institusional yang bersifat nasional karena arbitrase ini disediakan oleh organisasi tertentu dan sengaja didirikan untuk menampung perselisihan yang timbul dari perjanjian. Faktor kesengajaan dan sifat permanen ini merupakan ciri pembeda dengan arbitrase ad hoc. Selain itu, arbitrase oleh BANI ini sudah ada sebelum sengketa timbul yang berbeda dengan arbitrase ad hoc. Selain itu arbitrase oleh BANI ini berdiri untuk selamanya dan tidak bubar meskipun perselisihan yang ditangani telah selesai dan ruang lingkup keberadaan dan yurisdiksinya hanya meliputi kawasan negara yang bersangkutan.

Nyawa dari arbitrase adalah klausul arbitrase. Klausul arbitrase akan menentukan apakah suatu sengketa bisa diselesaikan melalui arbitrase, di mana diselesaikannya, hukum mana yang digunakan, dan lain-lain. Klausul arbitrase bisa berdiri sendiri atau terpisah dari perjanjian pokonya. Tidak ada keharusan dalam UU Arbitrase yang menentukan klausul arbitrase harus dibuat dalam akta notaris.Klausul arbitrase harus disusun secara cermat, akurat, dan mengikat. Tujuannya untuk menghindari klausul arbitrase tersebut digunakan oleh salah satu pihak sebagai kelemahan yang bisa digunakan untuk memindahkan sengketa tersebut ke jalur pengadilan.

BANI memberi standar klausul arbitrase sebagai berikut: "Semua sengketa yang timbul dari perjanjian ini, akan diselesaikan dan diputus oleh BANI menurut peraturan-peraturan prosedur arbitrase BANI, yang keputusannya mengikat kedua belah pihak yang bersengketa, sebagai keputusan dalam tingkat pertama dan terakhir".

Berdasarkan ketentuan Pasal 1 ayat (1) Undang-Undang Nomor 30 Tahun 1999 tentang Arbitrase, arbitrase adalah cara penyelesaian sengketa di luar peradilan umum yang didasarkan pada perjanjian arbitrase yang dibuat secara tertulis oleh para pihak yang bersengketa. Para pihak dalam perjanjian yang menghendaki agar penyelesaian sengketa yang timbul akan diselesaikan dengan arbitrase dapat mempergunakan salah satu dari dua cara yang dapat membuka jalan timbulnya perwasitan yaitu :

\section{- Pactum de Compromittendo}

Pactum de compromittendo berarti kesepakatan setuju dengan putusan arbiter.Bentuk klausul ini diatur dalam Pasal 2 UU No. 30 Tahun 1999, yang berbunyi sebagai berikut.

Undang-undang ini mengatur penyelesaian sengketa atau beda pendapat antarpara pihak dalam suatu hubungan hukum tertentu yang telah mengadakan perjanjian arbitrase yang secara tegas menyatakan bahwa semua sengketa atau beda pendapat 
yang timbul atau yang mungkin timbul dari hubungan hukum tersebut akan diselesaikan dengan cara arbitrase atau melalui alternatif penyelesaian sengketa. ${ }^{29}$

Pokok yang penting dalam ketentuan pasal tersebut, antara lain kebolehan untuk membuat persetujuan di antara para pihak yang membuat persetujuan, untuk menyerahkan penyelesaian perselisihan yang mungkin timbul di kemudian hari kepada arbitrase atau melalui alternatif penyelesaian sengketa. Persetujuan yang dimaksud adalah klausul arbitrase (arbitration clause). Berdasarkan hal tersebut, maka dapat ditarik kesimpulan bahwa klausul arbitrase dipersiapkan untuk mengantisipasi perselisihan yang mungkin timbul di masa yang akan datang. ${ }^{30}$

Mengenai cara pembuatan klausul pactum de compromittendo, tidak tegas diatur dalam Pasal 2 UU No. 30 Tahun 1999. Namun dari segi pendekatan penafsiran dan praktik, dijumpai dua cara yang dibenarkan, yaitu:

- Mencantumkan klausul arbitrase tersebut dalam perjanjian pokok. Ini cara yang lazim diterapkan dalam praktik, yaitu perjanjian pokokmenjadi satu kesatuan dengan klausul arbitrase. Persetujuan arbitrase yang berisi kesepakatan bahwa para pihak setuju akan menyelesaikan perselisihan (dispute) yang timbul di kemudian hari melalui forum arbitrase, dimuat dalam perjanjian pokok.

- Pactum de compromittendo dimuat dalam akta tersendiri atau terpisah dari perjanjian pokok. Apabila pactum de compromittendo berupa akta yang terpisah dari perjanjian pokok, waktu pembuatan perjanjian arbitrase harus tetap berpegang pada ketentuan, bahwa akta persetujuan arbitrase harus dibuat sebelum perselisihan atau sengketa terjadi. Hal itu harus sesuai dengan syarat formal keabsahan pactum de compromittendo, harus dibuat dibuat sebelum perselisihan timbul. ${ }^{31}$

\section{- Akta Kompromis}

Bentuk perjanjian arbitrase yang kedua disebut sebagai akta kompromis.Mengenai akta kompromis diatur dalam Pasal 9 UU No. 30 Tahun 1999:

- Dalam hal para pihak memilih penyelesaian sengketa melalui arbitrase setelah sengketa terjadi, persetujuan mengenai hal tersebut harus dibuat dalam suatu perjanjian tertulis yang ditandatangani oleh para pihak.

- Dalam hal para pihak tidak dapat menandatangani perjanjian tertulis sebagaimana dimaksud dalam ayat [1), perjanjian tertulis tersebut harus dibuat dalam bentuk akta notaris.

- Perjanjian tertulis sebagaimana dimaksud dalam ayat (1) harus memuat:masalah yang dipersengketakan; Nama lengkap dan tempat tinggal para pihak; nama lengkap dan tempat tinggal arbiter atau majelis arbitrase; tempat arbiter atau majelis arbitrase akan mengambil keputusan; nama lengkap sekretaris; jangka waktu penyelesaian sengketa; pernyataan kesediaan dari arbiter; dan pernyataan kesediaan dari pihak yang bersengketa untuk menanggung segala biaya yang diperlukan untuk penyelesaian sengketa melalui arbitrase.

- Perjanjian tertulis yang tidak memuat hal sebagaimana dimaksud dalam ayat (3) batal demi hukum.

\footnotetext{
${ }^{29}$ Pasal 2 Undang-Undang Nomor 30 Tahun 1999 Tentang Arbitrase dan Alternatif Penyelesaian sengketa.

${ }^{30}$ Frans Hendra Winarta, Hukum Penyelesaian Sengketa Arbitrase Nasional Indonesia dan Arbitrase Internasional, Jakarta, Sinar Grafika, 2013, Hal. 38-39.

${ }^{31}$ Ibid., Hal. 39.
} 
Berdasarkan ketentuan Pasal 9 UU No. 30 Tahun 1999 di atas, menurut penulis secara yuridis normatif dapat diketahui bahwa akta kompromis sebagai perjanjian arbitrase dibuat setelah timbul perselisihan antara para pihak atau dengan kata lain dalam perjanjian tidak diadakan persetujuan arbitrase. Dengan demikian, akta kompromis ialah akta yang berisi aturan penyelesaian perselisihan yang telah timbul di antara orang yang berjanji. ${ }^{32}$

Jadi berdasarkan analisis penulis di atas, berdasarkan pendekatan yuridis normatif penyelesaian sengketa bisnis melalui lembaga arbitrase dapat dilakukan dengan dua cara yaitu dengan factum de compromittendo, sebelum terjadi sengketa klausula arbitrase telah dicantumkan dalam perjanjian pokok, dan dengan melalui pembuatan akta kompromis setelah terjadi sengketa klausula arbitrase dibuat dalam bentuk tertulis terpisah dari perjanjian pokok. Sedangkan proses penyelesaian sengketa melalui lembaga arbitrase menurut Pasal 27 sampai dengan 60 Undang-Undang Nomor 30 Tahun 1999 Pemohon melakukan pendaftaran ke BANI dengan melengkapi syarat administrasi, uraian lengkap perkara dan tuntutan, dengan melampirkan akta perjanjian yang menurut klausula arbitrase dan pemohon menunjuk seorang arbiter. Berdasarkan ketentuan Pasal 60 Undang-Undang Nomor 30 Tahun 1999 bahwa keputusan lembaga arbitrase bersifat final dan mempunyai kekuatan hukum tetap dan mengikat para pihak, para pihak harus terikat dalam putusan arbitrase tersebut, walaupun pada tahap eksekusinya masih memerlukan keterlibatan Pengadilan Negeri.

\section{Eksekusi Putusan Lembaga Arbitrase dalam Penyelesaian Sengketa Bisnis}

Eksekusi putusan adalah realisasi kewajiban pihak yang bersangkutan untuk memenuhi prestasi yang tercantum di dalam putusan tersebut. Baik putusan hakim maupun putusan arbitrase, pada dasarnya memiliki makna yang tidak jauh berbeda, kedua putusan tersebut mengenal yang dinamakan putusan akhir. Putusan Pengadilan Negeri bersifat terbuka, karena seluruh proses acara persidangan sifatnya terbuka untuk umum, sehingga putusan hakim harus diucapkan dalam sidang yang dinyatakan terbuka untuk umum. Apabila tidak diucapkan dalam sidang terbuka, berarti putusan itu tidak sah dan tidak mempunyai kekuatan hukum.

Sedangkan putusan yang diucapkan dalam perkara arbitrase dilakukan dalam sidang tertutup, karena itu putusan arbitrase tidak boleh dipublikasikan. Putusan arbitrase dapat dikatakan sebagai putusan yang telah memiliki status dan kekuatan hukum yang setara dengan putusan hakim. Arbiter atau majelis arbiter akan mengambil keputusan berdasarkan keadilan dan kepatutan, dan putusan diucapkan dalam waktu paling lama 30 (tiga puluh) hari setelah pemeriksaan ditutup. Dalam waktu paling lama 30 (tiga puluh) hari terhitung sejak tanggal putusan diucapkan lembar asli atau salinan otentik putusan arbitrase, diserahkan dan didaftarkan oleh arbiter atau kuasanya kepada Panitera Pengadilan Negeri (Pasal 59 UndangUndang Nomor 30 Tahun 1999).

Setiap putusan hakim termasuk di dalamnya putusan arbitrase, pada prinsipnya mempunyai 3 (tiga) macam kekuatan :

- Kekuatan mengikat;

- Kekuatan pembuktian;

- Kekuatan eksekutorial atau kekuatan untuk dilaksanakan.

Putusan lembaga arbitrase selalu diberi tenggang waktu untuk melaksanakan secara suka rela oleh pihak-pihak yang bersengketa, tenggang waktu tersebut tidak diatur secara limitatif diserahkan kepada kebijakan Arbiter. Pelaksanaan eksekusi putusan lembaga arbitrase oleh Pengadilan Negeri digantungkan pada suatu syarat, bahwa putusan Arbitrase dalam tenggang

${ }^{32}$ Ibid., Hal. 40 
waktu 30 (tiga puluh) hari sejak putusan diucapkan harus didaftarkan pada kepaniteraan Pengadilan Negeri. Apabila dalam waktu 30 (tiga puluh) hari tersebut putusan Arbitrase tidak didaftarkan atau terlambat mendaftarkannya, maka putusan Arbitrase tersebut tidak dapat dilaksanakan atau non executable.

Prosedur pelaksanaan eksekusi atas putusan lembaga arbitrase tersebut diatur atau ditentukan dalam Pasal 59 sampai dengan 64 dari UU No. 30 Tahun 1999 memberi kewenangan kepada Ketua Pengadilan Negeri sebelum melaksanakan eksekusi tersebut untuk melakukan pengujian apakah putusan badan Arbitrase tersebut telah memenuhi syarat formil dan syarat materiil. Adapun yang dimaksudkan dengan syarat formil adalah kesepakatan para pihak bahwa sengketa mereka akan diselesaikan di lembaga arbitrase, kesepakatan tersebut harus tertuang dalam dokumen tertulis. Dan apakah sengketa mereka termasuk dalam sengketa bidang perdagangan dan mengenai hak yang menurut hukum dan peraturan perundang-undangan dikuasai sepenuhnya oleh pihak yang bersengketa. Selanjutnya yang disebut syarat materiel adalah, bahwa putusan lembaga arbitrase tidak bertentangan dengan kesusilaan dan ketertiban umum.

Berdasarkan analisis penulis di atas, secara yuridis normatif untuk melaksanakan putusan arbitrase yang tidak dilaksanakan secara sukarela terutama oleh pihak yang dinyatakan kalah dalam perkaranya, UU No. 30 Tahun 1999 memberikan satu bentuk pemaksaan kepada pihak yang tidak mau secara sukarela melaksanakan putusan Arbitrase tersebut, yaitu berupa eksekusi. Eksekusi arbitrase adalah upaya negara (dalam hal ini dilaksanakan oleh Pengadilan Negeri) untuk melaksanakan putusan dari lembag arbitrase (merupakan hukum privat) yang tidak dilaksanakan secara sukarela oleh para pihak, terutama pihak yang dinyatakan kalah. Pelaksanaan putusan (eksekusi) arbitrase merupakan produk hukum dari suatu lembaga (Institusi) dilaksanakan oleh lembaga (Institusi) lain. Dalam hal ini putusan lembaga arbitrase dilaksanakan oleh badan peradilan yaitu Pengadilan Negeri, sehingga menjadikan putusan lembaga arbitrase bersifat final and binding, dengan implikasi tidak ada upaya hukum atas putusan arbitrase, mengikat para pihak, efisiensi dan efektifitas merupakan karakteristik dari proses arbitrase.

\section{PENUTUP}

Penyelesaian sengketa bisnis melalui lembaga arbitrase dilakukan dengan dua cara yaitu melalui factum de compromittendo, sebelum terjadi sengketa klausula arbitrase telah dicantumkan dalam perjanjian pokok, atau melalui akta kompromis setelah terjadi sengketa klausula arbitrase dibuat dalam bentuk tertulis terpisah dari perjanjian pokok. Sedangkan proses penyelesaian sengketa melalui lembaga arbitrase menurut Pasal 27 sampai dengan 60 UndangUndang Nomor 30 Tahun 1999 dan memiliki keputusan lembaga arbitrase bersifat final dan mempunyai kekuatan hukum tetap dan mengikat para pihak, para pihak harus terikat dalam putusan arbitrase tersebut, walaupun pada tahap eksekusinya masih memerlukan keterlibatan Pengadilan Negeri.

Eksekusi putusan lembaga arbitrase dalam penyelesaian sengketa bisnis sebagaimana diatur dalam Pasal 59 sampai dengan 64 dari UU No. 30 Tahun 1999 dalam waktu paling lama 30 (tiga puluh) hari terhitung sejak tanggal putusan diucapkan, lembar asli atau salinan otentik putusan arbitrase diserahkan dan didaftarkan oleh arbiter kepada Panitera Pengadilan Negeri untuk dilakukan pengujian syarat formil dan syarat materil oleh Ketua Pengadilan Negeri yang menjadikan putusan lembaga arbitrase memiliki kekuatan hukum mengikat dan bersifat final and binding. 


\section{DAFTAR PUSTAKA}

Abdul R. Saliman. Hukum Bisnis Untuk Perusahaan: Teori dan Contoh Kasus, Jakarta: Kencana, 2010.

Abdulkadir Muhammad. Hukum Perdata Indonesia, Bandung, PT. Citra Aditya Bakti, 2009.

Bambang Sutiyoso. Hukum Arbitrase dan Alternatif Penyelesaian Sengketa, 2008, Gama Media, Yogyakarta, 2008.

Departemen Pendidikan dan Kebudayaan. Kamus Besar Bahasa Indonesia, Jakarta, Balai Pustaka, 1989.

Endang Purwaningsih. Hukum Bisnis, Bogor, Ghalia Indonesia, 2010.

Felix OS dan Fatma Jatno. Arbitrase Indonesia Beberapa Contoh Kasus dan Pelaksanaan dalam Praktek, Jakarta, Ghalia Indonesia, 1995.

Frans Hendra Winarta. Hukum Penyelesaian Sengketa Arbitrase Nasional Indonesia dan Arbitrase Internasional, Jakarta, Sinar Grafika, 2013.

Gunawan Widjaja dan Ahmad Yani. Hukum Arbitrase, Jakarta, PT Raja Grafindo Persada, 2003.

Huala Adolf. Hukum Penyelesaian Sengketa Internasional, Jakarta, Sinar Grafika, 2008

Joni Emirzon. Alternatif Penyelesaian Sengketa di Luar Pengadilan (Negosiasi, Mediasi, Konsiliasi \& Arbitrase), Jakarta, Gramedia Pustaka Utama, 2000.

M. Marwan, dan Jimmy P. Kamus Hukum (Dicionary of Law Complete Edition), Surabaya, Reality Publisher, 2009.

M. Yahya Harahap. Hukum Acara Perdata Gugatan Persidangan, Penyitaan, Pembuktian, dan Putusan Pengadilan, Jakarta, Sinar Grafika, 2008.

Maqdir Ismail. Pengantar Praktek Arbitrase di Indonesia, Malaysia, Singapura, dan Australia, , Jakarta, Universitas Al-Azhar Indonesia, 2007.

Munir Fuady. Arbitrase Nasional (Alternatif Penyelesaian Sengketa Bisnis), Bandung, PT. Citra Aditya Bakti, 2003.

Munir Fuady. Hukum Kontrak (Dari Sudut Pandang Hukum Bisnis), Bandung: PT Citra Aditya Bakti, 2007.

Peter Mahmud Marzuki. Penelitian Hukum, Jakarta, Kencana, 2014.

R. Subekti. Aneka Perjanjian, Bandung, PT. Citra Aditya Bakti, 1995.

R. Subekti. Pokok-Pokok Hukum Perdata, Jakarta, Intermasa, 2001.

Salim HS, dan Erlies Septianan Nurbani. Penerapan Teori Hukum Pada Penelitian Tesis dan Disertasi, Jakarta, PT RajaGrafindo Persada, 2013. 
Simatupang, Richard Burton. Aspek Hukum dalam Bisnis,Jakarta, PT. Rineka Cipta, 2003.

Sophar Maru Hutagalung. Praktik Peradilan Perdata dan Alternatif Penyelesaian Sengketa, Jakarta, Sinar Grafika, 2012.

Suyud Margono. ADR (Alternative Dispute Resolution) \& Arbitrase Proses Pelembagaan dan Aspek Hukum, Bogor, Ghalia Indonesia, 2004.

Kitab Undang-Undang Hukum Perdata.

Undang-Undang Nomor 30 Tahun 1999 Tentang Arbitrase dan Alternatif Penyelesaian Sengketa. 